\title{
MUO BAKASAI: \\ UPACARA BALIMAU KASAI DALAM KARYA TARI
}

\author{
Rizki Oktaviani \\ Jurusan Seni Tari, Fakultas Seni Pertunjukan, Institut Seni Indonesia Yogyakarta \\ Email: rizkiocktavia@gmail.com
}

\section{RINGKASAN}

Karya Muo Bakasai terinspirasi dari sebuah upacara tradisi Balimau Kasai di Kabupaten Kampar, Provinsi Riau. Balimau kasai merupakan sebuah upacara sebagai sarana penyucian diri, dan juga sebagai bentuk ucapan rasa syukur dan ungkapan kegembiraan menyambut datangnya bulan Ramadan, yang dilakukan oleh masyarakat Kabupaten Kampar di tepian Sungai Kampar. Tradisi ini juga dijadikan sebagai sarana silaturahmi untuk memperkuat rasa kekeluargaan dan persaudaraan antar sesama muslim dengan saling mengunjungi dan meminta maaf. Tradisi ini diawali dengan menyiapkan bahan ramuan yang akan digunakan untuk mandi yaitu air rebusan limau dan kasai. Kasai adalah ramuan wangi-wangian yang digunakan sebagai pelengkap mandi Balimau ini. Karya tari ini menggunakan tipe tari dramatik dengan pola garap koreografi kelompok delapan penari, empat penari putra dan empat penari putri, sebagai simbolisasi masyarakat yang melaksanakan tradisi Balimau Kasai. Bentuk penyajian karya ini adalah simbolis representasional, dengan tipe dramatik yang terdiri empat adegan yakni, introduksi, adegan satu, adegan dua dan adegan tiga. Gerak-gerak dalam karya ini disesuaikan dengan tema tentang penyucian diri dan kebersamaan, juga menggunakan beberapa unsur-unsur gerak dalam tari poncak daerah Kampar sebagai pola gerak dasar dalam karya ini.

Kata kunci: tradisi Balimau Kasai, Ritual, Muo Bakasai.

\begin{abstract}
Muo Bakasai's work was inspired by a Balimau Kasai tradition ceremony in Kampar regency, Riau Province. Balimau kasai is a ceremony as a means of self-purification, and also as a form of gratitude and expression of joy to welcome the coming of Ramadan, conducted by indigenous Kampar Regency on the banks of Sungai Kampar. This tradition is also used as a means of friendship to strengthen the sense of kinship and fraternity among fellow Muslims by visiting each
\end{abstract}


other and apologize. This tradition begins by preparing the ingredients that will be used to bathe the water of lime and chilli stew. Kasai is a perfumed herb used as a complement to this Balimau bath. The form of presentation of this work is symbolically representational. This work is packed with a dramatic type of dance, with four scenes namely introduction, scene one, scene two and scene three. The movements in this work are adapted to the theme of self-purification and togetherness, and also use some elements of motion in the Kampar Poncak dance as the basic motion pattern in this work.

Keywords: Balimau Kasai tradition, Ritual, Muo Bakasai

\section{PENDAHULUAN}

Balimau kasai merupakan sebuah upacara tradisional yang dilakukan masyarakat Kampar dalam rangka menyambut bulan suci Ramadhan dengan maksud untuk membersihkan diri dan mempersiapkan diri memasuki bulan Ramadhan. Acara ini dilaksanakan sehari menjelang masuknya bulan Ramadhan. Tradisi ini sudah dilakukan secara turuntemurun oleh masyarakat Kampar dan sekitarnya. Balimau Kasai adalah mandi dengan memakai limau dan kasai, ramuan yang digunakan sebagai pembersih dan pengharum badan. Tujuan mandi Balimau Kasai pada syariatnya adalah untuk membersihkan badan dari kotoran, namun pada hakikatnya didorong untuk memuliakan bulan suci Ramadhan dengan niat membersihkan badan, hati dan jiwa dari

${ }^{1}$ Zailani. 2005. "Balimau Kasai", dalam Sudirman Agus (editor), Puteri Si Kombang Bungo (Kumpulan Cerita Rakyat Daerah Kampar). Kabupaten Kampar: segala kekotoran sifat-sifat keduniawian.

Dahulunya Balimau Kasai menjadi upacara ritual masyarakat adat di sepanjang Sungai Kampar saja. Setelah tahun 60-an pemerintah mulai memberikan perhatian terhadap pelestarian kebudayaan, dan Balimau Kasai merupakan salah satu tradisi yang dapat menjadi bentuk promosi wisata budaya Kampar, maka dibuatlah acara yang melibatkan seluruh masyarakat dan dapat dihadiri oleh seluruh lapisan masyarakat baik dalam maupun luar daerah Kampar. ${ }^{1}$ Upacara bersih diri atau mandi menjelang memasuki bulan Ramadhan tidak hanya dimiliki masyarakat Kampar saja tetapi juga di berbagai daerah di Indonesia, hanya saja berbeda penyebutannya. Di Kampar upacara ini dikenal dengan nama Balimau Kasai, di daerah Pelalawan salah satu kabupaten yang ada di Provinsi Riau

Dinas Perhubungan, Pariwisata dan Seni Budaya Kabupaten Kampar, p. 213. 
JOGED

ISSN: 1858-3989

dikenal dengan nama Balimau Kasai Potang

Mamogang, di Sumatera Barat dikenal dengan nama Mandi Balimau, sedangkan beberapa daerah di Pulau Jawa lebih dikenal dengan nama padusan.

Balimau bermakna mandi dengan menggunakan air yang dicampur jeruk yang oleh masyarakat setempat disebut limau. Jeruk yang biasa digunakan adalah jeruk purut, jeruk nipis, dan jeruk kapas. Sedangkan kasai adalah sejenis ramuan yang dibuat sebagai pelengkap dalam acara mand $i$ balimau. Bahan ramuan untuk mandi balimau terbagi menjadi dua ramuan, ramuan limau dan ramuan kasai.

Ramuan limau terdiri dari limau purut, kumanyang, kabelu, urat sirih koduok, lengkuas padang, serai wangi, mayang pinang, daun nilam, urat siduo, urat sibuto, urat usau, bunga kenanga, bunga tanjung, dan bunga rampai. Semua bahan direbus sampai limau purut dapat hancur bila diremas. Ramuan kasai terbagi menjadi dua, kasai kering dan kasai basah. Bahan ramuan kasai kering ialah beras, coku/cekur dan kunyit, sedangkan bahan ramuan kasai basah ialah beras dan coku/cekur. ${ }^{2}$

Tata cara mandi Balimau Kasai adalah sebagai berikut: Sebelum melakukan Mandi Balimau, masyarakat terlebih dahulu

${ }^{2}$ Zailani. 2005. "Balimau Kasai", dalam Sudirman Agus (editor), Puteri Si Kombang Bungo (Kumpulan Cerita Rakyat Daerah Kampar). Kabupaten Kampar:
Rizki Oktaviani I MUO BAKASAI: UPACARA BALIMAU KASAI DALAM KARYA TARI

mempersiapkan ramuan yang dibutuhkan seperti ramuan limau dan ramuan kasai, setelah bahan siap, barulah bahan ramuan tersebut dibawa berarak-arakan dan diletakkan ke dalam wadah beserta makanan untuk makan bersama sebelum mandi balimau atau yang biasa disebut masyarakat sekitar dengan makan majamba. Barulah di tepian sungai, air rebusan limau dengan ramuan kasai tadi dimasukkan ke dalam sebuah wadah atau ember kemudian diaduk hingga kedua ramuan bercampur, lalu dengan niat membersihkan diri dan membaca Basmallah, air limau kasai tadi disiramkan mulai dari kedua telapak tangan dan kaki kemudian ke seluruh badan. Setelah yakin badan sudah bersih, barulah mereka menceburkan diri ke dalam Sungai Kampar, menyelam, bersuka ria.

Berdasarkan pemaparan di atas, ada hal yang menarik, bagaimana tradisi ini masih terus dilestarikan hingga saat ini, meskipun telah mengalami sedikit perubahan dalam hal ini tradisi ini sudah menjadi konsumsi seluruh masyarakat Kampar dan sekitarnya. Proses pelaksanaan tradisinya pun pada saat ini sedikit mengalami perubahan karena terdapat perayaan berupa lomba kapal hias yang selalu diikuti puluhan desa di sekitaran

Dinas Perhubungan, Pariwisata dan Seni Budaya Kabupaten Kampar, p. 217. 
Sungai Kampar. Tak hanya kapal hias, masyarakat juga turut serta merayakan dengan turun ke sungai untuk menghilir sungai menggunakan benen dan perahu karet demi dapat berpartisipasi dalam perayaan Balimau Kasai di Sungai Kampar. Di balik fakta mengenai tradisi Balimau Kasai terdapat nilai-nilai kehidupan yang terkandung di dalamnya, adalah nilai penyucian diri dan kebersamaan yang menjadi inti dari pelaksanaan Balimau Kasai. Hal inilah yang menginspirasi untuk menggambarkan nilai-nilai yang terkandung dalam tradisi Balimau Kasai ke dalam sebuah garapan tari.

\section{PEMBAHASAN}

\section{A. Konsep Penciptaan Tari}

\section{Kerangka Dasar Pemikiran}

Bersumber dari salah satu upacara tradisional Balimau Kasai di masyarakat Kabupaten Kampar, Provinsi Riau, karya Muo Bakasai terinspirasi oleh nilai-nilai yang terkandung dalam Balimau Kasai yakni tentang penyucian diri dan kebersamaan. Melalui karya ini dihadirkan suasana penyucian diri dari upacara Balimau Kasai dan rasa kebersamaan masyarakat dalam menyambut pelaksanaan tradisi Balimau Kasai yang dilaksanakan setahun sekali di sungai Kampar.

Dalam pengolahan materinya, dihadirkan beberapa tradisi atau kebiasaan masyarakat yang dilakukan masyarakat Melayu sebelum memulai suatu acara atau kegiatan tertentu sebagai permohonan doa keselamatan yaitu tradisi tepuk tepung tawar. Selain tepuk tepung tawar, juga ditampilkan berbalas pantun yang umumnya digunakan masyarakat Melayu sebagai pembuka suatu acara.

\section{Konsep Dasar Tari}

1. Rangsang Awal

Rangsang yang digunakan dalam proses penciptaan karya tari adalah rangsang ideasional, berdasarkan dari pengalaman melihat dan mengikuti upacara tradisional Balimau Kasai yang masih dilakukan di daerah Kampar. Ketertarikan terhadap tradisi Balimau Kasai memunculkan keinginan untuk menyajikan sebuah garapan koreografi yang bersumber dari tradisi Balimau Kasai dengan menghadirkan suasana prosesi pelaksanaan Balimau Kasai ke dalam sebuah garapan tari.

2. Tema Tari

Tema karya ini adalah penyucian diri dan kebersamaan. Terinspirasi dari beberapa rangkaian prosesi yang ada dalam pelaksanaan Balimau Kasai di antaranya, prosesi mandi dengan menggunakan bahan limau dan kasai, jalan berarak menuju tepian sugai, serta suka cita masyarakat saat perayaan Balimau Kasai di tepian sungai. 
JOGED

ISSN: 1858-3989

\section{Judul Tari}

Judul karya tari ini adalah “ MUO BAKASAI". Berdasarkan tradisi Balimau Kasai, balimau sendiri berarti berlimau atau mandi dengan menggunakan air jeruk limau dan kasai yang merupakan ramuan yang dipakai sebagai pelengkap dari tradisi Balimau Kasai. Judul karya ini diambil dengan maksud mengajak siapapun untuk ikut merasakan suasana dalam prosesi mandi Balimau Kasai. "Muo" yang merupakan bahasa masyarakat Kampar yang berarti "ayo" atau dengan maksud mengajak, dan "Bakasar" merupakan singkatan dari Balimau Kasai, yang juga diambil dari kata kasai yang merupakan salah satu bahan yang digunakan sebagai pelengkap dalam tradisi Balimau Kasai.

\section{Bentuk dan Cara Ungkap}

Bentuk dan cara ungkap, simbolis representasional. Konsep tipe tari dramatik ditampilkan dengan pembagian beberapa adegan. Karya ini terbagi ke dalam 4 adegan:

\section{a. Introduksi}

Introduksi merupakan adegan awal atau pembuka, sebagai penghantar karya kepada penonton. Introduksi ini menggambarkan tentang suasana sebelum prosesi Balimau Kasai, dengan menampilkan simbolisasi prosesi tepuk tepung tawar sebagai pembuka.
Rizki Oktaviani I MUO BAKASAI: UPACARA BALIMAU KASAI DALAM KARYA TARI

b. Adegan satu

Menggambarkan tentang aktivitas dan kesibukan masyarakat menjelang penyambutan pelaksanaan Balimau Kasai.

c. Adegan 2

Menggambarkan tentang aktivitas masyarakat menjelang turun ke sungai untuk melakukan prosesi mandi balimau. Aktivitas yang dihadirkan pada adegan ini adalah tentang kebersamaan. Adegan ini akan menampilkan penari yang berbalas pantun dan bersyair sebagai bagian dari tradisi masyarakat Melayu pada umumnya.

d. Adegan 3 atau Ending

Menggambarkan suasana kesakralan dari upacara Balimau Kasai, dengan menampilkan visualisasi dari prosesi mandi dalam upacara Balimau Kasai, yang dipimpin oleh seorang pemangku adat.

\section{Konsep Gerak Tari}

1. Gerak

Pemilihan gerak dalam karya tari ini dipilih berdasarkan tema yakni penyucian diri dan kebersamaan. Motif-motif gerak yang dipilih menggambarkan penyucian diri dan kebersamaan. Unsur-unsur gerak dalam Tari Poncak dipakai sebagai pola gerak dasar dalam karya ini. Tari Poncak adalah sebuah tari yang dijadikan sebagai sumber pijakan gerak dalam tari-tarian daerah Kampar. Ragam yang dipilih sebagai pola 
gerak dalam karya ini di antaranya adalah ragam Sepok, Olang Manyambau, dan Tandak Randai.

\section{Penari}

Karya tari Muo Bakasai disajikan ke dalam sebuah garapan koreografi kelompok dengan 8 (delapan) orang penari, empat penari putri dan empat penari putra. Pemilihan jenis kelamin laki-laki dan perempuan dalam karya ini adalah mewakili masyarakat daerah Kampar, laki-laki maupun perempuan yang semuanya melakukan tradisi Balimau Kasai.

\section{Musik Tari}

Musik dalam karya tari ini adalah iringan musik Melayu yang telah dikreasi dengan nuansa Melayu Kampar, dengan penata musik Roma Indrawan. Alat musik yang digunakan adalah saluang, akordion, tambur, bass, gambus, darbuka, kompang, cetik, dan gong. Musik dalam karya ini bersifat ilustrasi atau pendukung suasana, dengan maksud dapat mendukung terciptanya suasana dari pelaksanaan

\section{Balimau Kasai.}

\section{Rias dan Busana}

Pemilihan rias wajah pada karya ini menggunakan rias korektif, tidak ada menunjukkan karakter khusus pada rias ini, hanya berfungsi memperkuat garis-garis wajah penari. Riasan kepala pada penari perempuan menggunakan sanggul lipat pandan dan sanggul modern, dengan penambahan asesoris berupa bunga mawar dan asesoris berwarna emas.

Riasan kepala pada laki-laki, menggunakan songkok yang dibuat senada dengan bahan songket yang digunakan pada baju. Pemilihan warna yakni kain yang berwarna merah dengan perpaduan warna biru. Warna merah dipilih melambangkan semangat dan persaudaraan sedangkan warna biru diambil dari salah satu elemen dalam prosesi Balimau Kasai yakni air.

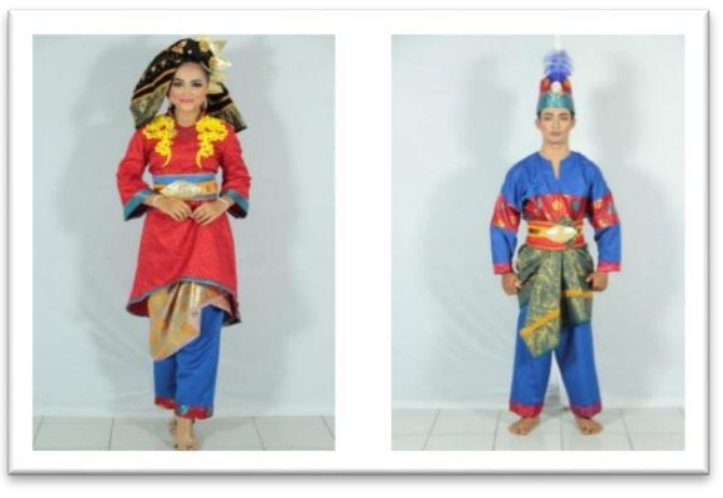

Gambar 1: Desain busana penari laki-laki dan perempuan (foto: Ari Kusuma, 2018)

4. Pemanggungan

a. Ruang Pementasan

Karya Muo Bakasai dipentaskan di panggung proscenium Jurusan Tari, Fakultas Seni Pertunjukan, Institut Seni Indonesia Yogyakarta. 
JOGED

ISSN: 1858-3989

b. Area / Lokasi Pementasan

Karya Muо Bakasai ini dipentaskan di gedung Auditorium Stage Jurusan Tari, Institut Seni Indonesia Yogyakarta, beralamatkan di jalan Parangtritis Km 6,5 Kecamatan Sewon, Kabupaten Bantul, Yogyakarta.

\section{c. Tata Cahaya}

Pemanfaatan tata cahaya dalam sebuah pertunjukan sangat membantu dalam menciptakan suasana di dalamnya, sehingga dapat memengaruhi suasana hati penonton. Tata cahaya dalam karya ini juga diharapkan dapat memperkuat suasana.

\section{d. Tata Rupa Pentas}

Tata rupa pentas dibutuhkan sebagai salah satu pendukung menciptakan suasana. Setting panggung yang digunakan dalam karya ini adalah, pada introduksi menggunakan trap berukuran $2 \times 1$ berjumlah 1 buah dan $1 \mathrm{x} 1$ berjumlah satu buah, dengan back drop bagian sisi kanan panggung diangkat ke atas. Kemudian pada bagian ending menggunakan trap atau level berukuran $2 \times 1$ berjumlah 3 buah dan $1 \times 1$ berjumlah 2 buah dengan latar belakang panggung yang ditutup dengan kain berwarna putih.
Rizki Oktaviani I MUO BAKASAI:

UPACARA BALIMAU KASAI DALAM KARYA TARI

\section{B. PROSES PENCIPTAAN TARI}

\section{Metode dan Tahapan Penciptaan}

a. Metode

Metode yang digunakan penata dalam proses penggarapan karya tari ini meliputi tahapan kreatif yaitu eksplorasi, improvisasi, komposisi, dan evaluasi.

1) Eksplorasi

Sebelum memberikan materi kepada penari, dilakukan kerja studio sebagai tabungan gerak untuk kemudian diberikan kepada penari. Selama proses eksplorasi mandiri yang dilakukan, penata biasanya mengajak Hakiki Darojat Saputra sebagai partner untuk mentransfer gerak-gerak yang ditemukan selama eksplorasi. Eksplorasi dilakukan berdasarkan tema yang dipilih yaitu, eksplorasi terhadap gerak-gerak yang menggambakan tentang kebersamaan dan penyucian diri.

2) mprovisasi

Improvisasi dilakukan untuk penemuan materi gerak yang lain secara kebetulan atau tidak disengaja. Cara ini dilakukan untuk mencari kemungkinan gerak baru yang dapat dijadikan sebagai motif dalam gerak yang digunakan. Dalam tahap ini, diberikan kebebasan kepada penari untuk bergerak dengan memberikan motivasi gerak dan memberikan gerak dasar yang dijadikan acuan untuk melakukan improvisasi. 
3) Komposisi

Komposisi dalam hal ini harus memperhatikan gerak, ruang, dan waktu, agar menjadi kemasan tari secara utuh. Pada proses komposisi ini digunakan beberapa pola-pola yang diadaptasi dari kesenian yang ada di daerah daerah Kampar yaitu randai Kampar yang menggunakan pola-pola garis lingkaran.

4) Evaluasi

Evaluasi dimaksudkan untuk melihat kekurangan-kekurangan yang terjadi selama proses latihan agar dapat dibenahi secara terus menerus. Evaluasi dapat membantu proses perbaikan karya sampai mencapai hasil yang diinginkan.

\section{Tahap Awal Penciptaan}

Proses penciptaan karya tari Muo Bakasai juga melewati beberapa tahapan awal di antaranya:

a. Proses Penentuan Ide dan Tema Penciptaan.

Objek dan ide penciptaan yang sudah ditetapkan, kemudian dikembangkan dengan melakukan observasi untuk memperkuat pengetahuan mengenai objek tersebut. Wawancara dengan narasumber yakni, Wan Harun Ismail dari Universitas Islam Riau. Proses panjang dilakukan dalam penentuan objek dan ide penciptaan, kemudian menetapkan tema.

Tema karya ini adalah penyucian diri dan kebersamaan. Tema karya ini dipilih berdasarkan makna dilakukannya upacara Balimau Kasai pada masyarakat tepian sungai Kampar dalam menyambut bulan suci Ramadhan.

b. Proses Penetapan Judul

Penetapan judul dalam karya ini dapat dikatakan tidak terlalu rumit. Judul ini dipilih berdasarkan pesan yang ingin sampaikan kepada penonton. Bahwasanya, penata ingin mengajak siapapun yang menikmati karya tari ini untuk mengenalkan tradisi Balimau Kasai yang masih dilestarikan di Kampar. Lalu dipilihlah judul karya "Muo Bakaasai" yang bermakna ajakan untuk mengenal dan mengingat kembali tentang tradisi Balimau Kasai.

c. Proses Pemilihan Penari

Pemilihan penari didasarkan tradisi ketubuhan penari. Dikarenakan keterbatasan penari laki-laki di Jurusan Tari ISI Yogyakarta, sehingga dipilih beberapa penari laki-laki dari Prodi Pendidikan Seni Tari, Universitas Negeri Yogyakarta. Para penari adalah Desi Ariani, Nia Lestari, Nur Aidilla Safitri, Tania Syahla Asha, Arifzani, Oki Fatra Widhiatmoko yang merupakan mahasiswa Jurusan Tari, Fakultas Seni Pertunjukan ISI Yogyakarta, dan Hakiki Darojat Saputra, Hengky Fitro Dinata yang merupakan mahasiswa Pendidikan Seni Tari Universitas Negeri Yogyakarta. 
JOGED

ISSN: $1858-3989$

d. Proses Penetapan Iringan dan Penata Musik

Komposer musik karya ini adalah Roma Indrawan, mahasiswa Etnomusikologi, Fakultas Seni Pertunjukan ISI Yogyakarta angkatan tahun 2016, yang berasal dari Riau. Pemusik lainnya yaitu Wahyu Pratama (Mahasiswa Etnomusikologi ISI Yogyakarta), Asry Budjana (Mahasiswa UAD), Muhammad Aryandy (Mahasiswa UTY), Ridho Dwi Dharma, Rizky Dwi Putra, dan Dian Bagaswara (Mahasiswa UMY) dan Donyka. Penata berdialog dengan komposer mengenai alat-alat musik yang akan digunakan dalam karya ini. Setelah proses pencarian dan pemantapan karya, alat-alat musik yang digunakan di antaranya gambus, biola, suling, tambur, bass, darbuka, cetik dan kompang.

e. Proses Penetapan Desain Rias dan Busana

Penata meminta bantuan kepada Soraya, mahasiswi Jurusan Etnomusikologi Pascasarjana ISI Yogyakarta sebagai penata rias wajah. Penata riasan kepala, adalah Rahma Fatmala, mahasiswi Jurusan Tari ISI Yogyakarta. Penata busana adalah Oki Fatra dan penjahit Awang. Busana yang dikenakan adalah baju yang didesain dengan pengembangan dari busana keseharian masyarakat Melayu yakni baju kebaya labuh
Rizki Oktaviani I MUO BAKASAI:

UPACARA BALIMAU KASAI DALAM KARYA TARI

untuk perempuan dan baju kurung untuk laki-laki.

\section{Realisasi Proses dan Hasil Penciptaan}

\section{a.Urutan Adegan}

1) Introduksi

Menampilkan empat orang laki-laki dan empat orang perempuan. Dua orang laki-laki di bagian upron simbolisai prosesi tepuk tepung tawar sebagai permohonan doa selamat, dua orang laki-laki di belakang back drop bagian kanan panggung menggambarkan seorang pemangku adat sebagai pemimpin dari upacara Balimau Kasai, empat orang penari putri di center sebagai penggambaran aktivitas masyarakat dalam mempersiapkan bahan-bahan untuk mandi balimau. 

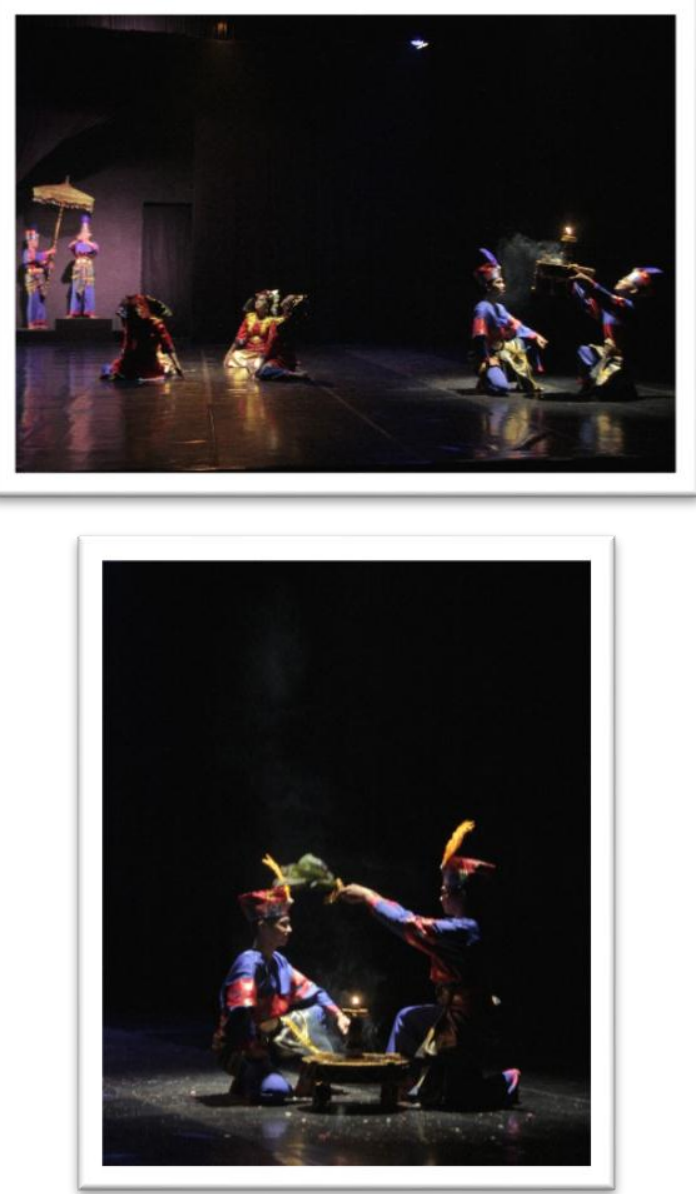

Gambar 2: Simbolisasi prosesi tepuk tepung tawar dalam adegan introduksi (foto: Ari Kusuma, 2018)

\section{2) Adegan 1}

Adegan ini memunculkan 4 penari laki dan 4 perempuan sebagai penggambaran aktivitas masyarakat baik laki-laki maupun perempuan, kemudian menampilkan 4 penari perempuan yang menggambarkan aktivitas ibu-ibu dalam mempersiapkan bahan dan ramuan untuk mandi balimau.
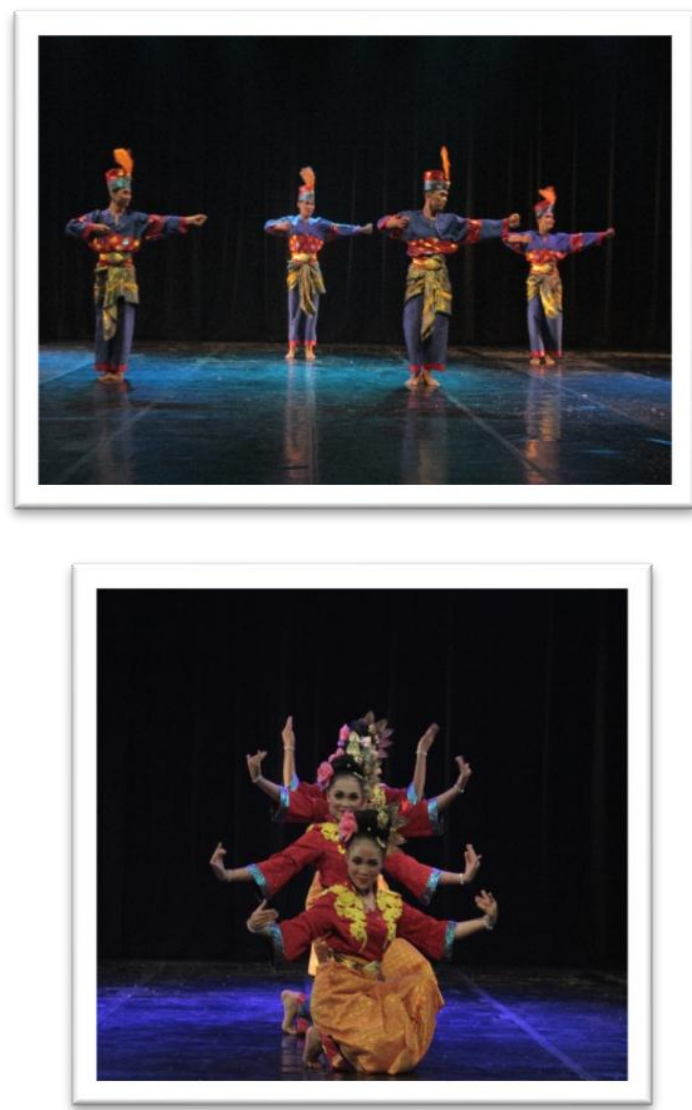

Gambar 3: Penggambaran aktivitas masyarakat (foto: Ari Kusuma, 2018)

3) Adegan 2

Adegan ini akan menghadirkan empat penari yang berbalas pantun. Berbalas pantun yang merupakan salah satu tradisi masyarakat Melayu yang digunakan sebagai sarana berkomunikasi, kemudian disusul dengan empat penari lainnya, bergerak menggambarkan kegiatan masyarakat menjelang prosesi balimau yang saling berinteraksi antar masyarakat. Adegan ini diolah dengan pola lingkaran, yang diadaptasi dari pola kesenian randai di daerah Kampar. 
JOGED

ISSN: 1858-3989
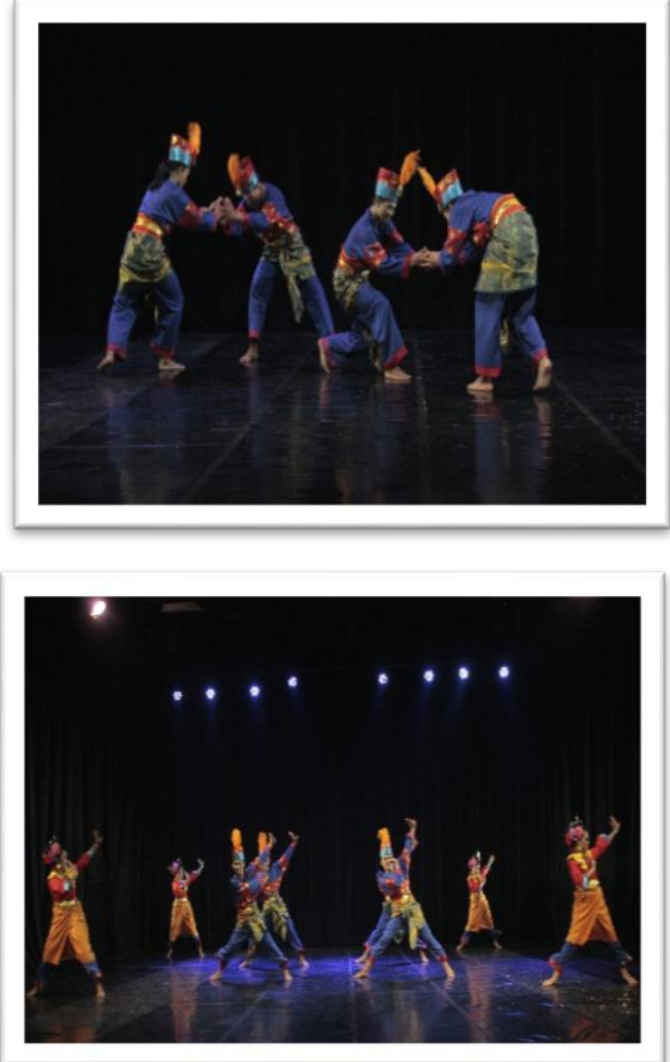

Gambar 4: Adegan 3 yang menggambarkan kebersamaan masyarakat (foto: Ari Kusuma, 2018)

\section{1) Adegan 3 atau Ending}

Seorang penari akan menjadi tokoh yang akan melakukan prosesi mandi balimau, penggambaran gerak seperti penyesalan terhadap diri dan dosa-dosa dalam dirinya. Seorang penari akan berperan sebagai pemangku adat dengan membawa kain putih yang digunakan untuk menutupi tubuh penari yang akan dimandikan, sedangkan penari lainnya membawa kendi. Penari yang membawa kendi, akan memecahkan kendi sebagai simbol dari membuang segala hal buruk dalam diri.
Rizki Oktaviani I MUO BAKASAI: UPACARA BALIMAU KASAI DALAM KARYA TARI
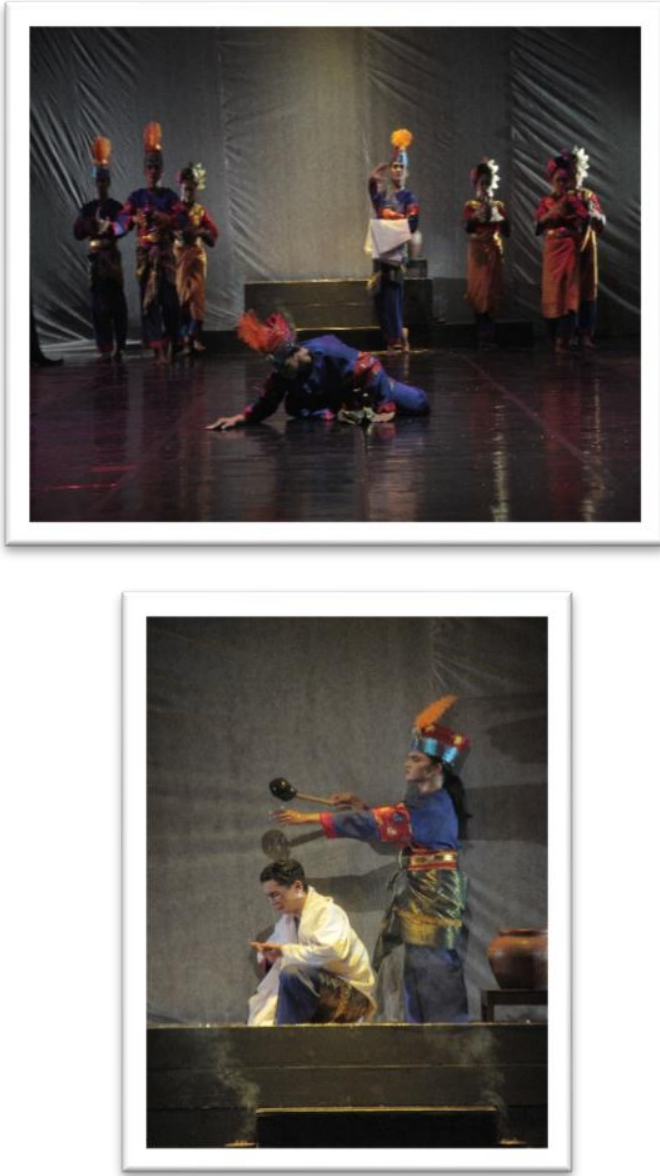

Gambar 5: Simbolisasi prosesi balimau kasai (foto: Ari Kusuma, 2018)

\section{B. Motif Gerak}

a. Motif Salam

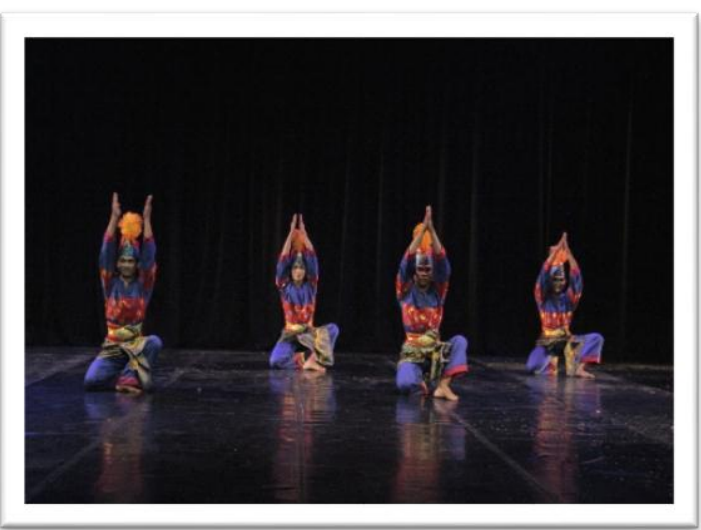

Gambar 6: Pose dalam motif gerak salam pada adegan 1

(Foto: Ari Kusuma, 04 Juni 2018, Stage Jurusan Tari ISI Yogyakarta) 
b. Motif Meracik Ramu

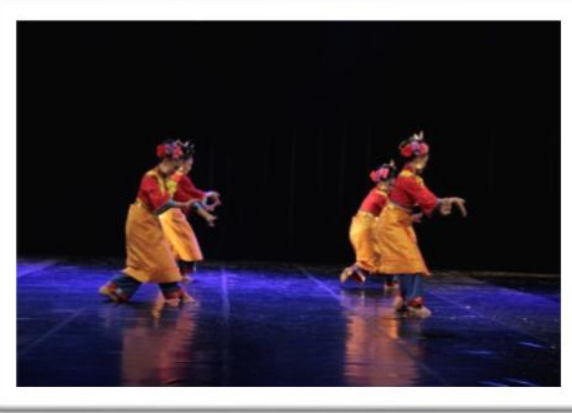

Gambar 7: Pose dalam motif gerak Racik Ramu pada adegan

(Foto: Ari Kusuma, 04 Juni 2018, Stage Jurusan Tari ISI Yogyakarta)

c. Motif Lotio

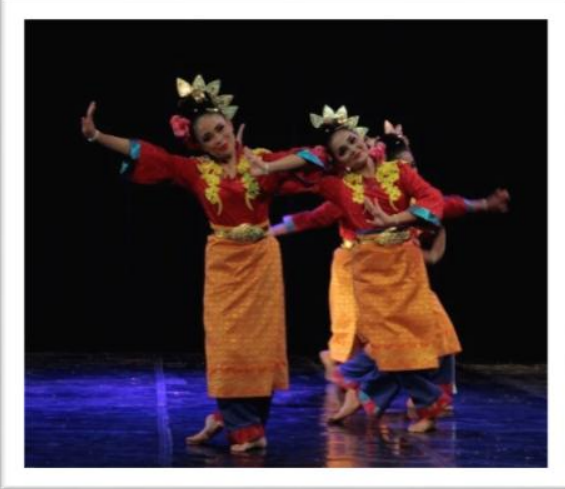

Gambar 8: Pose dalam motif gerak Lotio pada adegan 1

(Foto: Ari Kusuma, 04 Juni 2018, Stage JurusanTari ISI Yogyakarta)

\section{d. Motif Dayung}

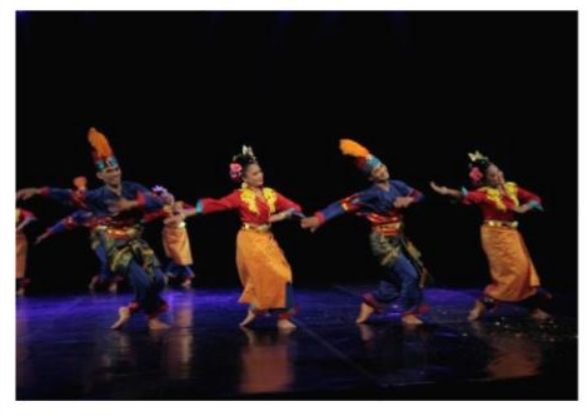

Gambar 9: Pose dalam motif gerak dayung (Foto: Ari Kusuma, 04 Juni 2018, Stage Jurusan Tari ISI Yogyakarta) e. Motif Lingkar Randai
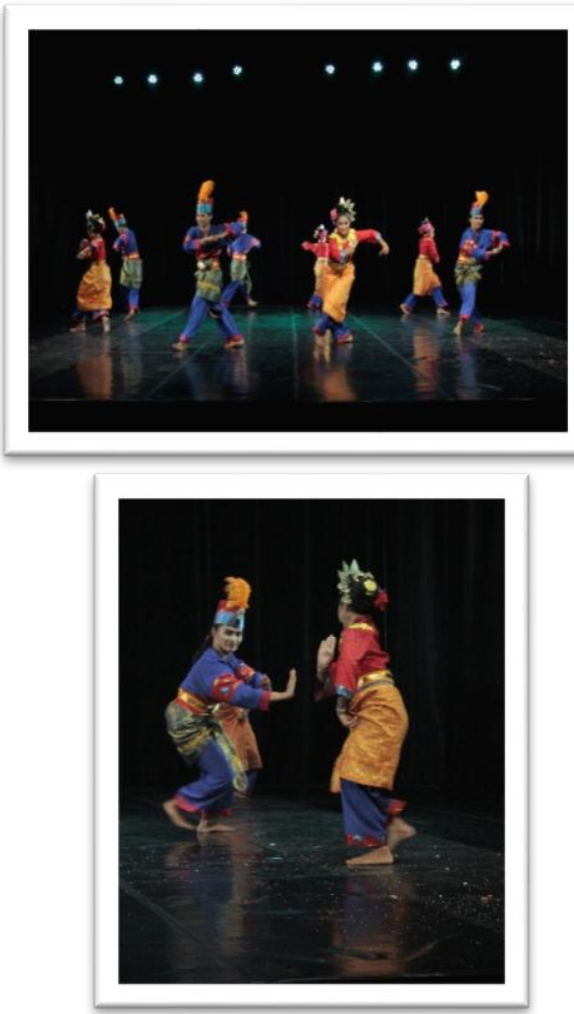

Gambar 10: Pose dalam motif gerak lingkar randai (Foto: Ari Kusuma, 04 Juni2018, Stage Jurusan Tari ISI Yogyakarta)

\section{f. Motif Basuh}

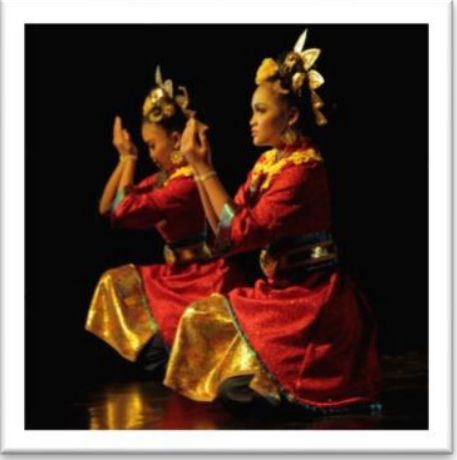

Gambar 11:

Pose dalam motif gerak basuh pada adegan 2

(Foto: Ari

Kusuma, 04

Juni2018, Stage

Jurusan Tari ISI Yogyakarta)

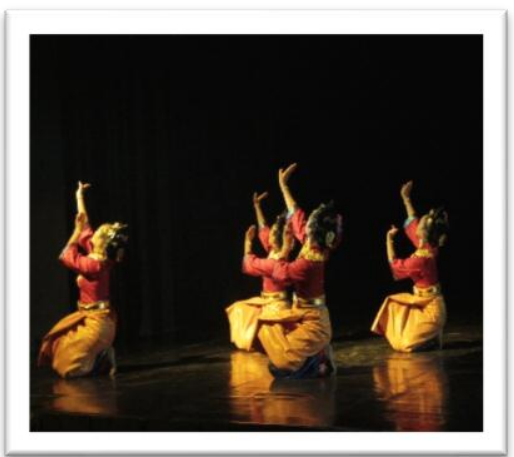


JOGED

ISSN: 1858-3989

\section{g. Motif Pacu Jalur}

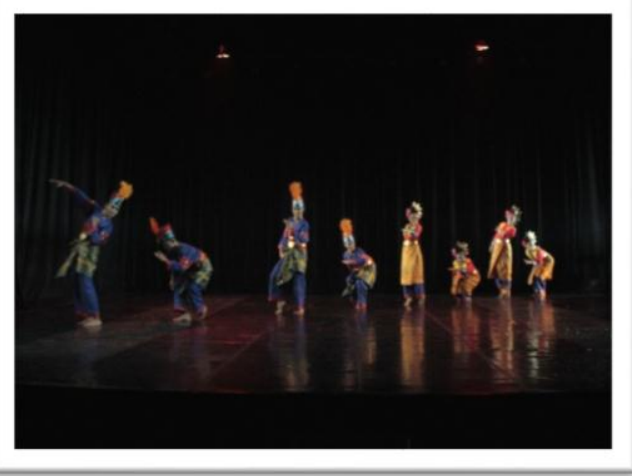

Gambar 12: Pose dalam motif gerak pacu jalur pada adegan 2

(Foto: Ari Kusuma, 04 Juni 2018, Stage Jurusan Tari ISI Yogyakarta)

h. Motif Berdoa
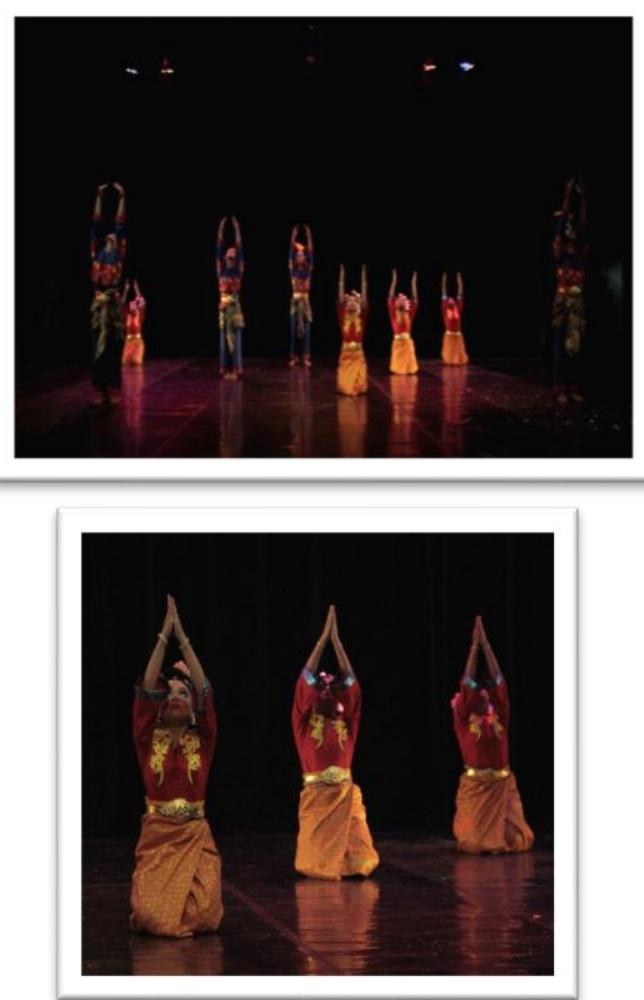

Gambar 13: Pose dalam motif gerak berdoa pada adegan 3

(Foto: Ari Kusuma, 04 Juni 2018, Stage Jurusan Tari ISI Yogyakarta)
Rizki Oktaviani I MUO BAKASAI: UPACARA BALIMAU KASAI DALAM KARYA TARI

\section{PENUTUP}

Muo Bakasai adalah sebuah karya tari yang merupakan hasil penuangan gagasan dan kreativitas yang dilatarbelakangi oleh sebuah upacara tradisi balimau kasai di Kabupaten Kampar, Provinsi Riau. Terinspirasi oleh nilai-nilai kebersamaan dan kesakralan pada prosesi penyucian diri, dengan pemilihan tema yakni kebersamaan dan penyucian diri.

Karya ini disajikan dalam bentuk garapan koreografi kelompok, dengan tipe tari dramatik dan dengan bentuk cara ungkap simbolis representasional dengan durasi, 17 menit 53 detik. Karya ini dikemas ke dalam empat adegan yaitu introduksi, adegan 1, adegan 2 dan adegan 3. Karya ini menghadirkan seorang penari yang berperan sebagai pemangku adat, dan seorang penari yang berperan sebagai seorang laki-laki yang melakukan prosesi mandi balimau kasai

Dalam proses penggarapannya digunakan metode eksplorasi, improvisasi, dan komposisi. Metode eksplorasi yang dilakukan bersadarkan tema yang dipilih dalam karya ini dan berdasarkan pengalaman ketubuhan penata, untuk kemudian diberikan kepada penari.

Gerak dalam karya ini menggunakan gerak-gerak dasar dalam tari Melayu, seperti petik bunga dan melenggang yang telah 
mengalami pengembangan. Karya ini menggunakan unsur-unsur gerak dalam tari poncak sebagai pola pijakan geraknya. Dalam prosesnya, diberikan kebebasan kepada penari dalam pencarian gerak, karena kenyamanan penari dalam bergerak sangat diperlukan untuk memperdalam rasa dari gerak tersebut.

\section{DAFTAR SUMBER ACUAN}

\section{A. Sumber Tertulis}

Agus, Sudirman. 2000. Budaya Daerah: Muatan Lokal Pendidikan Dasar Kabupaten Kampar, Kabupaten Pelalawan, dan Kabupaten Rokanhulu Provinsi Riau. Pekanbaru: Panca Abdi.

Agus, Sudirman. (ed). 2005. Puteri Si Kombang Bungo: Kumpulan Cerita Rakyat Daerah Kampar. Kampar: Dinas Perhubungan, Pariwisata dan Seni Budaya Kabupaten Kampar.

Anwar, Syair., Umar Amin, Ahmad Yusuf, dan Suwardi Ms. 1977/1978. Sejarah Daerah Riau. Proyek penelitian \& pencatatan kebudayaan daerah departemen pendidikan Kebudayaan

Ellfeldt, Lois. A Primer For Choreographers. 1977. Pedoman Dasar Penata Tari, terjemahan Sal Murgiyanto. Jakarta: Lembaga Pendidikan Kesenian Jakarta.

Hadi, Y.Sumandiyo. 2003. Aspek Aspek Dasar Koreografi Kelompok. Yogyakarta: Elkaphi.

Hadi, Y.Sumandiyo. 2006. Seni dalam Ritual Agama. Yogyakarta: Buku Pustaka.

Hadi, Y.Sumandiyo. 2007. Kajian Tari Teks dan Konteks. Yogyakarta: Pustaka Book Publisher.

Hadi, Y.Sumandiyo. 2017. Koreografi Ruang Proscenium. Yogyakarta:

Cipta Media \& BP.ISI Yogyakarta.

Hawkins, Alma. NM. Creating Through Dance. 1990. Mencipta Lewat Tari, terjemahan Y. Sumandiyo Hadi. Yogyakarta: Institut Seni Indonesia Yogyakarta.

Heriyawati, Yanti. 2016. Seni Pertunjukan dan Ritual. Yogyakarta :

Penerbit Ombak.

Husny, T.H.M. Lah. 1986. Butir-Butir Adat Budaya Melayu Pesisir Sumatera Timur. 
JOGED

ISSN: $1858-3989$

Jakarta: Proyek Penerbitan Buku Sastra Indonesia \& Daerah.

Jamil, O.K. Nizami. 2009. Pembakuan Tari

Persembahan (Provinsi Riau).

Lembaga Adat Melayu Riau.

M.A Effendi. 1989. Pakaian Adat Tradisional Daerah Riau. Departemen Pendidikan dan Kebudayaan: tanpa penerbit.

Martono, Hendro. 2010. Mengenal Tata

Cahaya Seni Pertunjukan.

Yogyakarta: Cipta Media.

Martono, Hendro. 2012. Koreografi Lingkunan, Revitalisasi Gaya Pemanggungan dan Gaya Penciptaan Seniman Nusantara. Yogyakarta: Cipta Media

Martono, Hendro. 2015. Ruang Pertunjukan dan Berkesenian.

Yogyakarta: Cipta Media.

Meri, La. Dances Composition the Basic Elements. 1986. Elemen-elemen Dasar Komposisi Tari, terjemahan Soedarsono, Yogyakarta: Akademi Seni Tari Indonesia.

Prasetyo, Yanu Endar. 2010. Mengenal Tradisi Bangsa. Yogyakarta:

IMU.
Rizki Oktaviani I MUO BAKASAI: UPACARA BALIMAU KASAI DALAM KARYA TARI

Samin, Suwardi Bin Mohammad. 2013. Diaspora Melayu Perantauan dari Riau ke Tanah Semenanjung. Yogyakarta: Pustaka Pelajar Bekerja sama dengan Alaf Riau Pekanbaru.

Sinar, Tengku Mira. 2011. Teknik Pembelajaran Dasar Tari Melayu Tradisional, Koreografi: Alm. Guru Sauti. Yogyakarta: Yayasan Kesultanan Serdang bekerjasama dengan Balai Kajian dan Pengembangan Budaya Melayu Yogyakarta

Smith, Jaqcueline. Dance Compotition: $A$ Practical Guide to Creative Succes in Dance Making. 1985. Komposisi Tari: Sebuah Petunjuk Praktis Bagi Guru. Terjemahan Ben Suharto. Yogyakarta: IKALASTI Yogyakarta.

Soedarso Sp. 2006. Trilogi Seni: Penciptaan, Eksistensi, dan Kegunaan Seni. Yogyakarta: BP ISI Yogyakarta.

Umar, Said Mahmud., Wan Ghalib, Marbakri, Burhan Yunus. 1977/1978. Adat Istiadat Daerah Riau. Proyek Penelitian dan Pencatatan Kebudayaan Daerah Departemen Pendidikan dan Kebudayaan. 
Widaryanto, F.X. 2009. Koreografi.

Bandung: Jurusan Tari STSI Bandung.

\section{B. Narasumber}

Sudirman Agus

Usia: 69 thn

Pekerjaan: Budayawan Kampar

Wan Harun Ismail

Usia: 32 thn

Pekerjaan: Dosen AKMR (Akademi Kesenian Melayu Riau)

\section{Discografi}

Video karya tari yang berjudul "Kampuong Taghondam" (2014).

Dapat dilihat di youtube.

Video komposisi "Tari Poncak" (2010) yang di publikasikan oleh Dinas Pariwisata dan Kebudayaan Kabupaten Kampar.

Video karya tugas akhir penciptaan tari ISI Yogyakarta dengan judul “Tun Fatimah" (2016) oleh Yola Utari Asmara. Dapat dilihat di youtube.

Video dokumentasi Upacara Adat Balimau Kasai Potang Mogang (2014). Dapat dilihat di youtube.

Video dokumentasi dengan judul "Balimau Kasai 2013 Batubelah" (2013). Dapat dilihat di youtube. 